\title{
REPRESENTASI TUBUH TRANSMAN DALAM FILM 3 GENERATIONS
}

\author{
${ }^{1}$ Deri Eka Firmansyah, Aquarini Priyatna, Lina Meilinawati Rahayu \\ Program Studi Magister Kajian Budaya, Fakultas Ilmu Budaya, \\ Universitas Padjadjaran \\ ${ }^{1}$ deriderij@gmail.com
}

\begin{abstract}
Abstrak
Artikel ini berjudul "Representasi Tubuh Transman dalam film 3 Generations. Artikel ini bertujuan untuk mengungkapkan fenomena transman yang merupakan variasi dari transgender, seperti yang direpresentasikan dalam film 3 Generation. Fokus dalam artikel ini adalah representasi transgender female-to-male, yang selanjutnya disebut sebagai transman dan konstruksi maskulinitas sebagaimana yang ditampilkan melalui film. Metode yang digunakan dalam penelitian ini adalah metode kualitatif dan deskriptif analitik untuk mendeskripsikan tubuh maskulin tokoh transman. Artikel ini mengungkapkan bahwa tokoh transman melakukan tindakan passing untuk menunjukkan dirinya sebagai laki-laki dalam tubuh maskulin. Tokoh transman artikel ini melakukan tindakan passing sebagai sebuah usaha untuk diterima sebagai seorang laki-laki. Artikel ini membuktikan bahwa transman mengekspresikan diri mereka sebagai laki-laki untuk memperlihatkan maskulinitas mereka.
\end{abstract}

Kata kunci: representasi, transman, 3 Generations

\section{Abstract}

This article entitled "The Representation of Transman Body in 3 Generations Movies". The aim of this is to reveal the transman phenomenon as a part of transgender diversie as represented in 3 Generations movies. It focuses on the representation of female-tomale transgender, also referred to as transman, and the construct of masculinity as expressed in the movies. By using qualitative and descriptive analytics methods, this article reveals how the transman character does the passing and reflects himself as a man in masculine bodies. Transman character in this movie does the passing as an effort to be accepted as a man. It proves that transman express themselves as men to show their masculinity.

Keyword: representation, transman, 3 Generations

\section{PENDAHULUAN}

Transman adalah bagian dari fenomena transgender, sebelumnya dikenal juga istilah "wadam", "bencong', atau "waria" bagi seseorang dengan kecenderungan untuk menampilkan gender atau identitas gendernya tidak selalu berkaitan dengan tampilan seks (genitalia). Istilah transman sendiri belum banyak dikenal untuk mengidentifikasi perempuan yang bertransisi menjadi laki-laki. Hines menjelaskan bahwa transgender adalah orang yang memiliki identitas gender atau ekspresi gender yang berbeda dengan seksnya yang ditunjuk saat lahir transgender juga terkadang disebut sebagai orang transseksual jika ia menghendaki bantuan medis untuk transisi dari satu seks ke seks lainnya (Hines, 2007: 19). Transgender merupakan 
bagian dari cairnya gender dan gender sebagai sebuah konstruksi sosial, selanjutnya pernyataan ini dikuatkan oleh pernyataan bahwa gender merupakan konstruksi sosiokultur yang disematkan pada seseorang (Butler, 1999: 9). Selain itu Beasley mengemukakan bahwa gender dalam kehidupan barat modern biasanya dikaitkan pada dua perbedaan dan kategori terpisah dari manusia (perbedaan perempuan dan laki-laki) begitu juga perbedaan praktek sosial dalam dua ranah (Beasley, 2005: 12). Dapat disimpulkan bahwa sebenarnya gender merupakan konstruksi sosial yang membentuk sifat laki-laki dan perempuan melalui pemberian identitas feminin pada perempuan dan maskulin pada laki-laki yang sebenarnya kedua hal tersebut dapat dipertukarkan. Selain itu gender secara khusus mengacu pada proses sosial yang membagi masyarakat dan praktek sosial dalam sebuah jalinan identitas kelamin.

Transman atau female-to-male transgender adalah perempuan yang merasa bahwa dirinya adalah laki-laki dan mengubah ciri seksual sekundernya sebagai seorang laki-laki. Transman melakukan banyak cara untuk mengubah stigma dirinya dari mulai dari menggunakan pakaian laki-laki, melakukan HRT atau hormon replacement theraphy untuk mengubah ciri seksual sekundernya dan melakukan operasi payudara sebagai langkah untuk menghilangkan atribusi perempuan dalam dirinya. Banyak hal yang dilakukan oleh transman untuk merepresentasi dirinya baik itu dalam dunia nyata ataupun dunia maya. Transman menghadapi banyak tantangan dalam merepresentasi dirinya di masyarakat. Tidak mudah bagi transman untuk melela pada orang-orang yang ada disekitarnya, mereka masih khawatir pada penolakan dari keluarga, hal yang paling ditakutkan dari seorang transman.

Objek dalam artikel ini adalah sebuah film dengan judul 3 Generations yang dibintangi oleh Elle Fanning, Naomi Watss, dan Susan Sarandon. Film ini disutradarai oleh Gabby Dellal dan Dorothy Berwin. Naskah film ini pun ditulis oleh Gabby Dellal dan Nikole Beckwith. Film 3 Generations diproduksi pada tahun 2014, dan pertama kali ditayangkan pada tahun 2015 pada Toronto International Film Festival dengan judul About Ray. Film tersebut baru secara resmi dirilis untuk publik pada tahun 2017 dengan mengganti judul sebelumnya menjadi 3 Generations. Film ini dipilih karena dianggap mampu merepresentasikan transman pada masa kini berikut dengan persoalan yang terjadi pada transisi diri transman.

Untuk membuktikan representasi tubuh yang dilakukan oleh transman digunakan teori representasi yang dikemukakan oleh Stuart Hall yang menyatakan bahwa representasi adalah adalah sebuah cara di mana memaknai apa yang diberikan pada benda yang digambarkan. Media juga merupakan aspek yang sangat besar pengaruhnya dalam membentuk sebuah arti dalam gambaran, pencitraan atau image yang diedarkan ke masyarakat luas, sehingga banyak aspek kehidupan kita yang dinilai wajar sebenarnya merupakan hasil dari bentukan media masa yang secara terus menerus memberikan informasi melalui representasinya (Hall, 1997: 17). Representasi yang ditunjukan oleh transman dalam film 3 Generations mengarah pada representasi tubuh dan seksualitas yang ditunjukan oleh transman dalam tubuh maskulinnya. Untuk membatasi permasalahan artikel ini yang akan dibahas adalah representasi tubuh maskulin yang ditunjukan oleh transman dalam film 3 Generations.

Tujuan dari penelitian ini adalah untuk mengetahui keberagaman gender yang direpresentasikan melalui film. Keberagaman tersebut merupakan sebuah bukti dari identitas gender cair yang ditampilkan melalui tokoh transman dalam film 3 Generations. Selain itu, artikel ini bertujuan untuk menunjukkan tubuh transman yang memproduksi tubuh maskulin sebagai upaya untuk menegaskan identitas tubuhnya sebagai seorang laki-laki. 


\section{METODE PENELITIAN/KAJIAN TEORI}

Metode yang digunakan dalam artikel ini adalah metode kualitatif. Metode kualitatif digunakan untuk mendeskripsikan pemahaman mendalam mengenai permasalahan yang diamati. Metode kualitatif dipilih karena data yang dihasilkan merupakan data deskriptif yang diambil dari film 3 Generations. Selain itu, artikel ini menggunakan pendekatan deskriptif analitik untuk menunjukkan tampilan tubuh maskulin yang diproduksi oleh tokoh transman dalam film 3 Generations.

Untuk mengungkapkan lebih dalam mengenai representasi diri dari transman, artikel ini mengacu pada teori representasi dari Stuart Hall yang menjelaskan representasi diri dari responden sebagai yang memproduksi identitas gender maskulin. Hall menekankan teori representasi memproduksi makna dan saling berbagi makna antara anggota sebuah kebudayaan yang memungkinkan memiliki pemahaman dan cara mengartikan makna yang sama (Hall, 1997: 14). Dalam kajian budaya makna dalam representasi dan media dipandang penting. Hall berpendapat bahwa relasi representasi adalah dengan media karena media dianggap telah memberikan sebuah penggambaran mengenai sebuah fenomena dengan segala nilai, kepentingan, serta ideologi yang implisit maupun eksplisit (Hall, 1997: 20).

Untuk merangkai analisis atas transman, saya mengacu kepada teori maskulinitas perempuan oleh Judith Halberstam, yang menyatakan bahwa maskulinitas merupakan sebuah konstruksi sosial. Maskulinitas dalam masyarakat tak bisa dielakkan dari gagasan kekuasaan, legitimasi, dan keistimewaan (Halberstam, 2002: 357). Hal tersebut seringkali menjadi sebuah simbol yang mengacu kepada kekuasaan negara dan kepada penyebaran kekayaan yang tidak merata. Maskulinitas diandaikan untuk menyebarkan pandangan keluar terhadap patriarki dan kedalam pada keluarga, maskulinitas menampilkan kekuasaan yang diwariskan, konsekuensi pergaulan dengan perempuan, dan harapan akan hak sosial istimewa (Halberstam, 2002: 365).

Argumen maskulinitas pun dibentuk dengan berbagai macam perbedaan seperti kelas, ras, seksualitas, dan gender (Halberstam, 2002: 368). Maka, sangat mungkin adanya 'maskulinitas dominan' yang muncul sebagai relasi yang natural antara atribusi laki-laki dan kekuasaan, dan hal tersebut membentuk secara sadar bahwa maskulinitas merupakan sebuah konstruksi sosial. Sementara itu, maskulinitas perempuan dijelaskan oleh Halberstam untuk mengeksplorasi posisi subjek queer bisa secara sukses menantang model hegemoni dari konformativitas gender (Halberstam, 2002: 290). Noble (2006) menjelaskan bahwa maskulinitas merupakan sebuah petanda bebas yang terpisah dari rujukan 'atribusi laki-laki' yang normatif. Selain itu Noble (2006) menyatakan maskulinitas perempuan dan transman menawarkan hal yang baru dalam politik gender, yaitu untuk mengonsep ulang dan mendekonstruksi maskulinitas terutama untuk laki-laki trans untuk memaknai cara pandang baru mengenai heteroseksualitas. Maskulinitas perempuan merupakan sebuah bentuk baru dari maskulinitas tanpa harus menampilkan maskulinitas normatif yang hanya ditunjukkan oleh laki-laki maskulin.

Pembahasan mengenai transman dalam artikel ini mengacu pada kajian transgender yang dikemukakan Richard Ekins dan Dave King melalui bukunya The Transgender Phenomenon. Ekin dan King (2006) menjelaskan bahwa transvestisme 
dan transseksual berasal dari dunia medis dan umumnya diadopsi oleh pelaku cross-dresser dan sex-changer. Ekin dan King (2006) menambahkan para pelaku medis menyebutkan bahwa transgender merupakan pelaku crossdresser yang menginginkan perubahan kelamin melalui proses medis dan ilmiah. Istilah tersebut merujuk pada crossdresser dan sex changer untuk mengidentifikasi dirinya sebagai seorang transeksual dan transvestis. Sementara itu, secara spesifik Rubin (2003) menyebutkan pengertian female-to-male transeksual merujuk pada seseorang yang bertransisi atau mengubah ekspresi seksualnya yang semula perempuan menjadi laki-laki. Menurut Ekin dan Ekin (2006), transman diidentifikasi sebagai ketegori masyarakat yang berbeda, menyimpang, sesat, abnormal, butuh pertolongan, dan lainnya. Merujuk pada pernyataan Ekin dan King, transman pada dunia normatif merupakan seseorang yang memerlukan bantuan karena dianggap menyimpang dan tidak sesuai dengan norma masyarakat. Kajian mengenai transgender juga bersifat intertekstual yang memadukan kajian akademik dengan autobiografi sehingga dalam kajian ini kita dapat melihat transgender bukan hanya sebagai individu secara budaya, tetapi dari berbagai sisi kehidupan sebagaimana ditampilkan pada film.

Penanda atas tubuh yang dilakukan transman adalah dengan menggunakan pakaian laki-laki atau pun usaha untuk menunjukkan tanda-tanda seksual sekunder sebagai laki-laki. Argumen tersebut dikuatkan oleh pernyataan Halberstam (1998) yang menyebutkan transgender berbusana sesuai dengan gender yang diinginkan, meskipun tak semuanya mampu melakukan operasi untuk menegaskan kelamin mereka. Penanda maskulin yang ditunjukan oleh transman merupakan langkahlangkah untuk meyakinkan masyarakat bahwa mereka bagian yang tidak berbeda dari laki-laki pada umumnya. Penggunaan pakaian dan modifikasi tubuh dimaknai sebagai tindakan passing atau melintas identitas. Aaron (2001) menjelaskan bahwa passing merupakan sebuah langkah yang dilakukan untuk dapat memberikan ilusi terhadap masyarakat terkait dengan gender yang ditujunya. Menurut Aaron (2001) passing dalam konsep transman merupakan sebuah usaha untuk dapat menyembunyikan identitas asli dan menampilkan identitas yang sesuai pada khalayak ramai. Selain itu, menurut Aaron (2001), passing merupakan perilaku yang dinamis, bisa sukses ataupun gagal bergantung dari modifikasi penampilan yang ditunjukkan.

Tindakan passing merupakan sebuah kesadaran bahwa transman mengalami disporia gender atau merasa bahwa gendernya tidak sesuai dengan kelamin yang dimilikinya. Menurut Rubin, transman selalu meyakini bahwa dirinya terlahir sebagai seorang laki-laki meskipun ada dalam tubuh perempuan (Rubin, 2003: 31). Selain itu, Rubin (2003) berpendapat bahwa para transman memiliki kesadaran tubuh, citra tubuh, dan peluang untuk tahapan tubuh kedua yaitu fisik utuh sebagai laki-laki. Untuk mendapatkan fisik laki-laki, transman melakukan modifikasi tubuh seperti mengenakan pakaian laki-laki dan tindakan medis seperti terapi hormon testosteron. Rubin (2003) menjelaskan pengaruh testosteron adalah untuk memperlihatkan kategori seks sekunder, untuk menunjukkan ciri-ciri umum seorang laki-laki. Sementara itu, untuk ciri-ciri fisik lainnya diperlukan langkah-langkah medis lainnya.

Tindakan passing tidak hanya dimaknai melalui pakaian dan transisi medis, tetapi melalui penggunaan jamban. Halberstam (2002) menjelaskan bahwa persoalan jamban menjadi sangat krusial bagi transman. Bagi mereka jamban laki- 
laki merupakan representasi dirinya untuk masuk ke dalam area khusus pria tanpa harus diketahui. Apabila transman mampu untuk passing dengan menggunakan jamban laki-laki, secara tidak langsung mereka sudah diakui dalam identitas gender laki-laki.

\section{PEMBAHASAN}

Dalam artikel ini akan diungkapkan bagaimana identitas gender maskulin yang memproduksi tubuh direpresentasi melalui film 3 Generation melalui tindakan passing yang dilakukan oleh tokoh transman. Tindakan passing dilakukan tokoh transman untuk dapat dikenali sebagai laki oleh orang-orang yang ada di sekitarnya. Pada tahap ini akan dijelaskan relasi antara fluiditas gender terhadap identitas gender seseorang, termasuk konsep maskulinitas yang tidak didentikkan dengan laki-laki. Perempuan pun bisa merepresentasi tubuh dan identitas maskulin seperti dapat ditampilkan melalui pertunjukan drag king, transvestisme, hingga transgender. Selain itu representasi tubuh yang diargumenkan dalam artikel ini adalah identitas gender yang cair menunjukkan bahwa sebenarnya gender pun bisa dipertukarkan dan merupakan bagian dari gender sebagai bagian dari konstruksi sosial.

Isu passing yang ditampilkan oleh tokoh transman merupakan relasi dari identitas gender maskulin yang diperlihatkan oleh transgender female-to-male atau yang dalam artikel ini akan disebut transman dengan teori representasi yang dikemukakan oleh Stuart Hall. Akan diargumentasikan pula bagaimana tokoh transman dalam film 3 Generations melakukan tindakan passing dalam masyarakat normatif. Dengan menunjukkan relasi yang merepresentasikan citra diri yang berupa tubuh dan informasi yang berkaitan dengan transman, lambang-lambang yang direlasikan pada transman dan dapat dipaparkan representasi tubuh maskulin yang dicitrakan oleh transman. Adegan yang memperlihatkan relasi penerimaan keluarga terhadap tubuh tokoh transman dapat dipertimbangkan sebagai bentuk penerimaan tubuh maskulin transman sebagai laki-laki pada umumnya dan keberhasilan transman melakukan tindakan passing untuk dapat dikenali sebagai laki-laki.

Seorang transman akan merepresentasikan dirinya sebagai seorang lakilaki sebagai citra eksplisit dirinya. Sesuai dengan pernyataan Hines (2007) yang menjelaskan penggunaan busana berkebalikan dengan kelamin merupakan perlawanan dan tantangan pelaku transgender antara kelamin secara biologis dan penampilan gender yang berlawanan untuk melihat tanggapan masyarakat terhadap dirinya. Hal tersebut merupakan usaha passing dari tokoh transman sebagai upaya memproduksi identitas sebagai seorang laki-laki.

Film 3 Generations menampilkan tokoh utama Ray atau Ramona seorang transman yang melakukan usaha untuk dapat diakui sebagai laki-laki di lingkungannya. Usaha yang dilakukan Ray untuk dapat dikenal sebagai laki-laki adalah melalui tindakan passing yakni merepresentasi dirinya dalam tubuh laki-laki. Persoalan passing menjadi penting bagi transman untuk menampilkan tubuh sebagai laki-laki dan menutupi atribusi perempuan yang melekat pada tubuhnya. Menurut tiga portal film daring, film 3 Generations mendapatkan rating 5,8/ 10 di IMDb, Rotten Tomatoes memberikan rating $32 \%$, sedangkan Metacritic memberikan nilai rata-rata dan rating untuk film tersebut sebesar 47/ 100 dari 21 kritikus atau reviewer. 


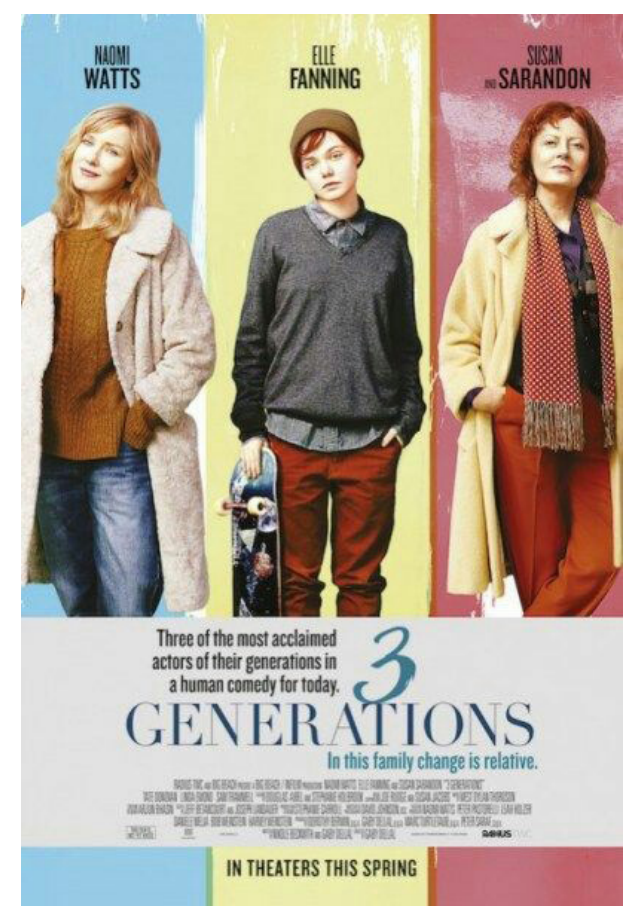

Gambar 1. Poster film 3 Generations (sumber: www.imdb.com)

Film 3 Generations menceritakan tiga generasi nenek, ibu, dan seorang anak pada sebuah keluarga yang tinggal pada satu rumah di kota New York. Keluarga ini menghadapi permasalahan saat tokoh utama Ramona atau Ray yang dibintangi Elle Fanning akan melakukan tindakan passing menjadi seorang transman. Ray yang sudah mengidentifikasi diri dan hidup menjadi seorang laki-laki akan memulai terapi hormon untuk menegaskan gendernya. Film ini berjalan pada dua plot utama. Fokus plot pertama adalah Ray atau Ramona yang ingin segera melakukan tahap selanjutnya dari transisi transgender yakni terapi hormon. Fokus pada plot kedua adalah pergulatan keluarga terutama ibu dari Ray, Maggie, untuk menerima transisi Ray sebagai seorang laki-laki dan meyakinkan orang lain untuk dapat menerima transisi yang dilakukan oleh putranya. Yang menyambungkan kedua plot tersebut adalah isu passing atau usaha yang dilakukan untuk dapat dikenali dan diidentifikasi sebagai laki-laki yang dilakukan oleh Ray. Passing merupakan sebuah usaha yang dijalankan oleh transman untuk memulai perjalanan kehidupannya sebagai seorang laki-laki. Ketika proses passing berhasil, atribusi perempuan yang melekat pada diri transman sudah tidak nampak lagi.

Maskulinitas yang ditampilkan oleh tokoh transman merupakan sebuah usaha untuk dapat diterima sebagai seorang laki-laki. Dalam usahanya untuk memperlihatkan tubuh maskulinnya, tokoh Ray bertelanjang dada dan membuat payudaranya tidak nampak, Ray ditunjukkan untuk menampilkan dirinya sebagai seorang 'laki-laki'. Dalam hal ini karena tubuh adalah penanda utama maskulinitas yang ditampilkan oleh transman, bertelanjang dada merepresentasikan maskulinitas Ray. Dengan tindakan tersebut juga Ray melawan stigma yang dilekatkan kepadanya sebagai seorang transgender. 
Untuk dapat bertelanjang dada tokoh Ray harus melakukan modifikasi tubuh agar dapat diterima sebagai laki-laki. Modifikasi tubuh transman dilakukan untuk menampilkan tubuh laki-laki agar diakui pada masyarakat modern. Dalam film ditampilkan Ray sedang bercermin dan membebat dadanya menggunakan kain agar payudarannya tidak menonjol. Pembebatan payudara merupakan sebuah usaha untuk modifikasi tubuh sehingga payudara yang merupakan atribusi perempuan yang dimiliki oleh Ray tidak nampak. Payudara yang dimiliki oleh transman dianggap sebagai sebuah beban dan bukan bagian dari tubuhnya sehingga payudara sebagai penanda seksual perempuan yang harus dihilangkan ketika transman berusaha menampilkan dirinya sebagai laki-laki. Memiliki payudara akan secara distingtif mengafirmasi identitas seksual seseorang sebagai perempuan. Seperti yang disampaikan oleh Rubin (2003), dada menjadi bagian tubuh yang paling ingin dihilangkan oleh transman, karena tidak nyaman dan mereka merasa dada merupakan sebuah beban. Tokoh Ray menahan payudara mereka menggunakan nilon, perban bahkan lakban untuk menyembunyikan payudara untuk memberikan ilusi payudara yang tidak nampak. Teknik menyembunyikan payudara ini merupakan sebuah usaha dari transman sebelum melakukan operasi pengangkatan payudara dan yang paling penting sebagai usaha untuk passing atau diterima sebagai laki-laki.

Tanpa melakukan modifikasi tubuh, kebanyakan transman mengkhawatirkan diri mereka disalah kenali oleh orang lain. Dengan bertelanjang dada Ray memperlihatkan dirinya sebagai laki-laki dalam tubuh maskulin dengan kebiasaan laki-laki pada umumnya yaitu bertelanjang dada. Bertelanjang dada merupakan sebuah bentuk kemerdekaan seorang transman karena lepas dari kekangan dan meskipun Ray belum melakukan operasi payudara, dengan bertelanjang dada Ray menyetarakan dirinya seperti lelaki pada umumnya. Adegan Ray bertelanjang dada ini merupakan perlawanan terhadap konformativitas gender yang dilakukan untuk memperlihatkan maskulinitas dirinya. Topik maskulinitas perempuan mengemuka untuk mengeksplorasi posisi subjek queer bisa secara sukses menantang model hegemoni dari konformativitas gender (Halberstam, 2002: 290). Ray menolak konformativitas gender yang didasarkan pada kelamin yang melekat pada dirinya sebagai perempuan karena dirinya menganggap tubuhnya sebagai identitas queer tidak memilih diantara gender biner.

Bertelanjang dada dimaknai sebagai kemerdekaan Ray sebagai seorang lakilaki. Bertelanjang dada merupakan hak istimewa dari seorang laki-laki yang ingin ditunjukkan oleh Ray untuk memproduksi tubuh yang maskulin. Sementara itu, cermin merupakan sebuah media di mana Ray dan penonton mampu mengamati perubahan tubuh yang dialami oleh Ray. Selain itu dalam adegan Ray bertelanjang dada di depan cermin, kamera yang mengikuti proses Ray melepaskan kain yang membebat payudara merupakan sebuah refleksi masyarakat yang memperhatikan setiap perubahan yang dijalani oleh transman. Pembebatan payudara dalam konsep passing menutupi penanda dirinya sebagai seorang perempuan, untuk memperlihatkan tubuhnya sebagai laki-laki. Akan tetapi, payudara yang ditutupi tersebut merupakan sebuah pengingkaran terhadap tubuhnya sendiri. Bebat yang disematkan pada payudaranya menjadi sebuah pengingat bahwa dirinya bukan laki-laki, tetapi juga bebat dimaknai sebagai sarana untuk membuat tubuhnya seperti laki-laki.

Modifikasi tubuh dengan menutupi payudara merupakan simbol terlepasnya segala femininitas yang ada pada tubuhnya. Pengingkaran yang 
dilakukan oleh Ray merupakan bentuk tindakan memfiksasi tubuhnya sebagai lakilaki. Transman memiliki kesadaran tubuh, citra tubuh, dan peluang untuk tahapan tubuh kedua yaitu fisik utuh sebagai laki-laki. Kesadaran tubuh yang dimaknai oleh Ray merupakan disporia gender, di mana Ray merasa bahwa kelaminnya tidak sesuai dengan gender yang dimilikinya. Itu mengapa Ray menginginkan modifikasi tubuh untuk menegaskan identitas dirinya sebagai seorang laki-laki.

Setelah melakukan usaha untuk membuat payudaranya terlihat rata, tokoh Ray melakukan tindakan passing dengan menggunakan pakaian laki-laki untuk dapat diterima sebagai seorang laki-laki di lingkungannya. Ray mengenakan pakaian lakilaki baik ketika beraktivitas di rumah maupun di sekolah. Tokoh Ray menggunakan kemeja flanel, celana panjang longgar, jaket, hingga mantel yang cukup longgar untuk menutupi tubuh perempuannya dan memperlihatkan tubuhnya sebagai seorang laki-laki. Selain mengenakan pakaian laki-laki, tokoh Ray pun memotong rambutnya pendek untuk menampilkan diri sebagai seorang remaja laki-laki. Pakaian dalam konteks transisi yang dilakukan transman adalah usaha untuk passing atau melintas gender sehingga pakaian tersebut menjadi sebuah penanda dari gender yang dituju. Suthrell (2004) menerangkan penggunaan busana dalam transvestisme merupakan sebuah demonstrasi sebagaimana pentingnya pakaian untuk identitas. Begitu pun dalam konsep transman, untuk menampilkan identitas sebagai seorang laki-laki yang biner, pakaian digunakan sebagai sebuah penanda identitas maskulin. Menurut Suthrell (2004), pakaian dalam konsep biner merupakan metafora yang menjelaskan pemahaman penanda dan coding lokal untuk memperlihatkan identitas tertentu. Ray menunjukkan identitas dirinya sebagai seorang laki-laki dengan menggunakan pakaian yang sesuai dengan gendernya. Penggunaan pakaian merupakan sebuah upaya menggiring opini publik terhadap identitas maskulinnya.

Passing merupakan sebuah tujuan yang diharapkan oleh transman untuk menampilkan performativitas gendernya, tetapi apabila penampilannya kurang memadai transman melakukan tindakan modifikasi yang lebih permanen melalui prosedur medis. Prosedur medis yang dilakukan pertama adalah dengan menjalankan terapi hormon. Terapi hormon merupakan langkah yang dilakukan untuk dapat menegaskan ciri sekunder sebagai laki-laki. Dalam film ini Ray sangat menantikan terapi hormon untuk dapat diterima secara luas sebagai laki-laki, bukan hanya di lingkungan keluarga. Untuk melakukan terapi hormon, tokoh Ray dan ibu juga neneknya melakukan kunjungan dan konsultasi pada dokter. Informasi yang diberikan dokter meliputi bagaimana hormon testosteron berpengaruh terhadap perubahan tubuh. Rubin (2003) berpendapat transman percaya bahwa testosteron memiliki pengaruh pada tubuh dan sikap mereka dalam gagasan tubuh laki-laki juga maskulinitas. Mereka percaya bahwa testosteron merupakan sumber dari tubuh lakilaki dan beberapa transman lain percaya bahwa testosteron juga asal dari perilaku sosial maskulin. Dengan dimulainya terapi hormon Ray akan menjalani kehidupan yang baru sebagai laki-laki pada umumnya, menghilangkan ciri-ciri seksual sekundernya sebagai seorang perempuan. dan menegaskan dirinya sebagai seorang laki-laki.

Maskulinitas yang umum pada masyarakat ditandai dengan atribusi lakilaki yang dinormakan, seperti lahir sebagai laki-laki dan memperlihatkan identitas yang macho. Hal tersebut ditampilkan oleh Ray melalui pakaian dan modifikasi tubuh. Passing yang dilakukan transman adalah untuk mengkonfirmasi identitas diri sebagai seorang laki-laki. Selain itu, maskulinitas yang ditampilkan melalui 
tubuh Ray merupakan sebuah petanda bebas yang terpisah dari rujukan 'atribusi laki-laki' yang normatif. Itu mengapa tampilan diri Ray bukan hanya sekedar macho dan maskulin dalam konteks normatif, tetapi pada konsep maskulinitas yang lebih luas. Transman memaknai maskulinitas perempuan yang menjadikan maskulinitas bukan hanya pada bentuk atribusi laki-laki normatif yang terkungkung pada nilai dan memiliki hak istimewa. Selain itu, Halberstam (1998) menjelaskan untuk memperlihatkan identitas maskulin beberapa transgender tidak mendefinisikan dirinya atas keinginan yang kuat untuk memiliki penis, tapi lebih berkeinginan untuk memproduksi identitas laki-laki. Keinginan Ray untuk passing dan bertransisi bukan untuk mendapatkan hak istimewa sebagai laki-laki ataupun citra laki-laki dalam dunia normatif, melainkan penerimaan diri sebagai laki-laki seutuhnya dan menyesuaikan gendernya sesuai dengan identitas yang dimaksud.

Identitas gender yang dicitrakan oleh transman merupakan usaha untuk mengubah paradigma maskulinitas yang biasanya diidentikkan dengan dengan atribusi laki-laki yang normatif. Maskulinitas perempuan dan transman menawarkan hal yang baru dalam politik gender, yaitu untuk mengonsep ulang dan mendekonstruksi maskulinitas terutama untuk laki-laki trans untuk memaknai cara pandang baru mengenai heteroseksualitas. Pernyataan tersebut dikuatkan oleh tokoh Ray dianggap sebagai bagian dari laki-laki dan maskulinitas yang dimaknai beragam dalam konsep maskulinitas perempuan ini. Karena dalam maskulinitas perempuan konsep atribusi laki-laki yang menjadi identitas diri dikonstruksi ulang dan bisa dipertukarkan tidak berdasarkan pada konsep laki-laki yang umum.

Permasalahan yang mengemuka ketika Ray akan melakukan terapi hormon adalah ketika dokter mengharuskan perizinan yang ditandatangani oleh ayah kandung yang tak pernah ditemuinya. Perizinan tersebut merupakan sebuah langkah awal bagi transman untuk mendapatkan suntikan hormon testosteron untuk pertama kali. Permasalahan muncul ketika ayah kandung dari Ray mempertanyakan motivasi dari perubahan diri Ray dan menolak menandatangani surat perjanjian tersebut. Penolakan tersebut karena ayah Ray menganggap dia belum mengenal terlalu jauh terhadap diri Ray dan memiliki permasalahan dengan ibu kandungnya. Perizinan yang harus ditandatangani oleh orang tua kandung merupakan sebuah bentuk legalisasi dari identitas yang ingin ditampilkan oleh Ray. Identitas perempuan yang ingin dihilangkan dan identitas laki-laki yang ingin dikekalkan oleh Ray akan terjadi apabila kedua orang tuanya menandatangani surat untuk melakukan terapi hormon.

Tokoh dokter menjelaskan mengenai transisi yang akan diterima Ray sebagai seorang transman. Perubahan tubuh ini dianggap sebagai penegasan atas citra tubuh laki-laki yang dilakukan oleh Ray. Pernyataan Rubin menguatkan pemaknaan penegasan identitas tubuh atas diri Ray. Transman yang melakukan transisi tidak mengubah kepribadiannya, tetapi hanya tubuhnya seperti kepompong yang bermetamorfosis menjadi kupu-kupu. Pada hakikatnya transman bukan mengubah dirinya dari perempuan menjadi laki-laki, mereka hanya memperbaiki relasi tubuh dengan identitas gender mereka. Dengan terapi hormon yang dijalani oleh Ray penegasan terhadap gendernya akan semakin jelas, yang mulanya dia hanya diidentifikasi sebagai tomboy apabila sudah melakukan transisi dia dapat diakui sebagai laki-laki. Terapi hormon ini yang menjadi isu penting dalam film 3 Generations karena dalam menjalani terapi hormon diperlukan izin dari kedua pihak keluarga untuk menegaskan identitas diri dari Ray. 
Proses passing yang dijalani oleh Ray merupakan upaya penegasan identitas diri sebagai seorang laki-laki. Dalam kaitannya dengan tindakan passing melalui pembebatan payudara, Gardiner (2012) menyatakan identitas yang dibangun oleh transman mengacu pada penubuhan, tetapi dengan usaha untuk mengonfirmasi tubuh mereka untuk menegaskan identitas diri sebagai seorang laki-laki sehingga mereka bisa dikenali sebagai laki-laki oleh orang lain. Banyak transman menganggap diri mereka sabagai "laki-laki sesungguhnya", tetapi mereka butuh teknologi untuk membentuk tubuh yang utuh sebagai laki-laki atau mengaitkan tubuh mereka sesuai dengan identitas diri yang sebenarnya. Itu mengapa Ray sangat bersungguhsungguh untuk melakukan modifikasi tubuh agar setelah tindakan passing yang ditampilkannya berhasil dia sepenuhnya diterima sebagai laki-laki. Karena melalui modifikasi tubuh, atribusi perempuan yang melekat bisa dihilangkan. Rubin (2003) menjelaskan mengenai langkah yang dilakukan oleh transman untuk memperlihatkan citra dirinya, mereka memodifikasi tubuh mereka untuk mengekspresikan identitas yang sebenarnya. Meskipun memiliki atribusi tubuh perempuan, Ray mengekspresikan identitas laki-laki. Bukan hanya tomboy atau pun menunjukan citra diri lesbian yang maskulin, tetapi juga menubuhi konsep laki-laki yang ada dalam ideologi gendernya. Tanpa adanya modifikasi, Ray mengkhawatirkan adanya kekaburan dalam mengidentifikasi identitasnya. Rubin (2003) menjelaskan tanpa modifikasi tubuh, kebanyakan transman mengkhawatirkan diri mereka disalahkenali oleh orang lain, yang mereka maknai bahwa salah mengenali identitas gender mereka disebut sebagai sebuah bentuk opresi karena seringkali orang salah berpersepsi terhadap transman yang disangka sebagai seorang butch atau dyke.

Penerimaan keluarga penting bagi Ray sebagai transman untuk dapat menampilkan identitas diri yang utuh sebagai seorang laki-laki. Penerimaan Ray sebagai laki-laki merupakan sebuah urgensi karena Ray merasa bahwa identitas dirinya sebagai perempuan merupakan sebuah opresi karena tidak sesuai dengan kelaminnya. Itu mengapa penerimaan keluarga menjadi penting untuk membangun identitas dirinya sebagai laki-laki seutuhnya.

Sebelum melakukan coming out atau melela pada keluarga, Ray pertama kali mengekspresikan gendernya sebagai laki-laki pada teman-temannya. Teman-teman terdekat Ray menerima perubahan yang terjadi pada dirinya dengan menghiraukan identitas sebelumnya sebagai perempuan. Setelah melela pada teman-temannya, Ray melela pada ibunya yang juga menerima transisi Ray sebagai anak laki-laki. Ibu Ray, Maggie adalah keluarga terdekat pertama yang mengubah panggilan Ramona menjadi Ray. Meskipun teman-temannya menerima secara utuh diri Ray sebagai seorang laki-laki, hal tersebut tidak terlalu penting. Penerimaan keluarga sangat penting untuk menegaskan diri Ray sebagai laki-laki.

Sebelum benar-benar diterima dalam identitas diri sebagai seorang laki-laki, Ray mengalami penolakan oleh neneknya. Neneknya yang lesbian menganggap bahwa lebih mudah apabila Ray merepresentasikan diri sebagai lesbian. Menurut anggapan neneknya, tidak ada perbedaan dari lesbian yang mencitrakan dirinya sebagai butch atau dyke dengan seorang transman. Dalam kehidupan masyarakat yang luas transman seringkali disalahartikan dan dimasukan kedalam kategori lesbian. Respon yang diberikan nenek Ray adalah mengeneralisasi bahwa apa yang dialami oleh cucunya sama seperti penampilan maskulin yang ditampilkan oleh lesbian. Dolly, nenek Ray, mewakili masyarakat yang masih menganggap bahwa transman 
sama dengan perempuan tomboy yang merepresentasi diri dengan identitas lakilaki. Padahal, tubuh yang ditampilkan oleh transman bukan perempuan butch atau dyke, tetapi tubuh laki-laki yang ada pada diri perempuan. Pemikiran tersebut mewakili pemikiran normativitas pada masyarakat yang masih berpendapat bahwa gender masih ada dalam konsep biner.

Ray sebagai seorang transman akhirnya diakui oleh neneknya yang selama ini menolaknya. Neneknya masih menganggap bahwa menjadi lesbian merupakan hal yang lebih mudah daripada melakukan transisi menjadi transman. Penerimaan neneknya atas tubuh maskulin Ray merepresentasi penerimaan masyarakat yang lebih luas. Hal tersebut ditandai melalui pernyataan Dolly, nenek Ray, yang menyatakan bahwa, "sudah saatnya di keluarga ini memiliki seorang anak laki-laki". Penerimaan Ray sebagai laki-laki oleh Dolly, merupakan pemikiran bahwa identitas gender yang semula biner dapat diterima sebagai sesuatu yang cair. Keluarga tersebut yang selama ini tidak memiliki sosok laki-laki, mendapatkan anak laki-laki dengan transisi sebagai transman. Meskipun ada dalam keluarga yang queer, adanya laki-laki di keluarganya dianggap sebagai pelindung dan pelengkap di keluarganya yang hanya terdiri dari perempuan saja. Transisi yang dilakukan transman dianggap irasional oleh orang yang ada di sekitarnya yang selalu menganggap perempuan yang mengubah diri menjadi laki-laki bertujuan untuk mendapatkan hak istimewa lakilaki. Ray juga mengalami penolakan dari ayah kandungnya. Selain belum mengenal lebih dekat pribadi Ray, ayah kandungnya merasa transisi yang dilakukan Ray memerlukan pertimbangan kembali. Penolakan ini terjadi karena ayah dan nenek Ray tidak mengalami dan memahami konsep gender disporia yang terjadi pada diri transman. Dari film tersebut, dapat diargumentasikan bahwa transman berusaha untuk bisa dikenali atau passing sebagai seorang laki-laki. Ekspresi gender yang dicitrakan oleh Ray sebagai laki-laki merupakan usaha dirinya agar bisa diterima oleh lingkungan meskipun terdapat pertentangan dan penolakan dari masyarakat.

Berkaitan dengan seringnya salah pemaknaan terhadap diri transman, Halberstam (1998) menyatakan banyak transman yang secara sukses mengidentifikasi dirinya sebagai butch dalam komunitas queer perempuan sebelum memulai transisi gender. Hal tersebut terjadi karena pada mulanya mereka mengidentifikasi diri mereka sebagai seorang lesbian yang menampilkan citraan yang maskulin. Lebih lanjut Halberstam (1998) menyatakan banyak wacana mengenai transseksual sekarang menjadikan peran sebagai lesbian pada masa lalu seorang transman sebagai contoh dari kesalahan identitas atau sebagai sebuah usaha untuk mencari tempat perlindungan sementara dalam beberapa variasi gender queer dalam konsep butch. Meskipun dalam film tersebut tidak ditunjukan Ray terlibat pada komunitas lesbian, dalam perjalanan transisi seorang hal itu dimulai dari menampilkan diri sebagai seorang butch. Butch dimaknai sebagai representasi awal yang ditampilkan perempuan lesbian yang menampilkan maskulinitasnya.

Sebelum melakukan transisi menjadi transman, Ray merepresentasikan diri sebagai seorang tomboy. Halberstam (2002) menyatakan tomboy dikaitkan awal mula kesadaran terhadap perbedaan antara gender dan kelamin. Hal ini menunjukan bahwa tomboy merupakan bagian awal dari maskulinitas perempuan yang biasanya timbul di masa kecil anak perempuan dan tidak menjadi kekhawatiran orang tua. Tomboy cenderung dikaitkan dengan hasrat alamiah untuk kebebasan dan pergerakan yang didapatkan oleh anak laki-laki. Dalam film 3 Generations keluarga 
cukup lama untuk dapat menerima diri Ray sebagai seorang laki-laki. Anggapan keluarga yang mulanya menganggap bahwa tomboy adalah hal yang lumrah pada diri Ray, hingga keluarga tidak menjadikan perilaku tomboy dari Ray bukan masalah besar. Tomboy pada diri Ray ketika kecil dimaknai sebagai kebebasan dan keberanian seorang anak perempuan dalam menjalani kehidupannya. Perilaku tomboy tersebut pun ditandai oleh cita-cita yang diinginkan oleh Ray ketika kecil yaitu pembalap dan penolakannya untuk menggunakan pakaian perempuan. Pada akhirnya harapan dari ibu Ray untuk mendapatkan putri kecil harus hilang karena perubahan identitas tomboy menjadi transisi transman.

Selanjutnya dibahas penerimaan keluarga terhadap Ray yang melakukan transisi sebagai seorang laki-laki dan sudah dianggap sebagai seorang 'laki-laki' seutuhnya dengan sebutan 'anak laki-lakiku' dan kata ganti orang kedua laki-laki atau 'he' yang disematkan pada Ray. Orang pertama yang memanggil Ray dengan kata ganti laki-laki adalah ibunya. Ibu dari Ray memulai menyebut anaknya dengan anak lelakiku, memperlakukan Ray sebagai anak laki-laki dan berjuang pada anggota keluarga yang lain agar Ray dianggap sebagai seorang laki-laki. Usaha yang dilakukan oleh ibu dan Ray untuk bisa dipersepsi sebagai laki-laki membuahkan hasil, karena seluruh keluarga perlahan-lahan menerima Ray sebagai seorang lakilaki. Pengakuan sangatlah penting dalam representasi diri seorang transman karena pemaknaan terhadap tubuhnya bukan hanya menjadi otoritas tubuhnya sendiri melainkan sudah diakui oleh orang-orang disekitarnya. Penyebutan panggilan 'he' adalah sebuah pembuktian bahwa Ray dalam tubuh laki-laki di lingkungan keluarganya membuat dirinya merasa utuh sebagai seorang laki-laki.

Representasi dirinya sebagai seorang transman bisa kita lihat dari beberapa adegan yang ditampilkan melalui ibu dan nenek dari Ray. Meskipun Ray sudah bertransisi menjadi laki-laki, mereka tidak melupakan dirinya pada masa lalu sebagai seorang perempuan. Meskipun perubahan itu sudah terjadi, representasi feminin dirinya di masa lalu adalah sebuah sejarah yang perlu dikenang. Maskulinitas yang ditampilkan perempuan dan transman menawarkan hal yang baru dalam politik gender, untuk mengonsep ulang dan mendekonstruksi maskulinitas terutama bagi laki-laki trans untuk memaknai cara pandang baru mengenai heteroseksualitas. Fotofoto tersebut mendekonstruksi pengertian mengenai maskulinitas yang melekat pada diri laki-laki. Karena bukan hanya laki-laki yang terlahir secara kelamin saja yang dapat menampilkan maskulinitasnya, tetapi perempuan pun mampu menampilkan citra yang maskulin melalui transisinya sebagai transman.

Dalam film 3 Generations, tokoh Ray mengalami kekerasan yang dilakukan oleh teman sekolahnya. Ray mengalami kekerasan verbal dan fisik ketika melakukan sebuah perjalanan. Kekerasaan verbal yang terjadi pada Ray adalah ejekan dan risakan bahwa Ray bukan laki-laki, Ray seorang perempuan, dan mengejek Ray sebagai seorang lesbian. Selain itu kekerasan fisik terjadi setelah olok-olok, Ray dianiaya oleh temannya sehingga menyebabkan luka fisik. Kekerasan fisik yang terjadi pada Ray merupakan sebuah bentuk penolakan terhadap atribusi laki-laki yang ditampilkan oleh transman. Pelaku kekerasan masih menganggap bahwa transman merupakan hal yang menyimpang dan dianggap mengganggu privilege maskulinitas laki-laki. Masih banyaknya pandangan negatif dan kurangnya pengetahuan mengenai transman membuat kekaburan, penilaian buruk terhadap representasi diri mereka sebagai laki-laki. Representasi tubuh yang dilakukan oleh 
transman dalam film 3 Generations merupakan penggambaran citra diri sebagai lakilaki dan usaha melakukan edukasi pada masyarakat agar diri mereka diterima secara utuh sebagai laki-laki.

Selanjutnya dalam dalam film 3 Generations dijelaskan persoalan jamban yang sering kali terjadi pada transman. Jamban dianggap penting bagi transman untuk menampilkan diri sebagai seorang laki-laki. Ada scene di mana Ray menuju ke jamban sekolah, tetapi Ray tidak memilih untuk masuk ke jamban perempuan atau pun jamban laki-laki. Karena belum melakukan transisi secara penuh, Ray lebih memilih untuk menggunakan toilet di restoran yang tidak ditujukan bagi gender tertentu. Di antara jamban perempuan dan jamban laki-laki terdapat sebuah poster yang berisi slogan 'conserve humanity' atau lestarikan kemanusian. Slogan tersebut merupakan sebuah tanda dari kemanusiaan yang terenggut dari pelaku transgender, yang menggunakan jamban sesuai dengan tampilan gendernya.

Persoalan jamban menjadi sangat krusial bagi transman. Bagi mereka, jamban laki-laki merupakan representasi dirinya untuk masuk ke dalam area khusus pria tanpa harus diketahui. Walaupun ada ketakutan dari transman untuk diketahui dan dianiaya, tetapi dalam kecenderungan itu laki-laki tidak terlalu waspada terhadap orang-orang yang ada di sekitarnya. Hal ini berbeda dengan MTF (male to female), transgender yang rawan untuk memasuk area perempuan karena perempuan cenderung lebih mengamati dengan detil orang-orang yang ada di sekitarnya. Itu mengapa Ray menggunakan jamban tanpa penanda gender untuk menghindari kekerasan dan kesalahpahaman terhadap gendernya.

\section{PENUTUP}

Artikel ini menunjukkan bagaimana film 3 Generation telah menampilkan konstruksi gender non-normatif dalam bentuk transman, yakni perempuan yang merepresentasikan diri dan tubuhnya sebagai laki-laki. Transman menampilkan identitas maskulin untuk dapat diterima sebagai laki-laki oleh masyarakat melalui tindakan passing. Tokoh utama dalam film 3 Generations menunjukkan bahwa representasi tubuh maskulin yang dicitrakan oleh tokoh transman dalam artikel ini membuktikan bahwa konstruksi laki-laki bukan hanya dimaknai pada tubuh lakilaki normatif, tetapi juga tubuh laki-laki pada diri transman. Keberhasilan tokoh transman untuk melakukan passing adalah bentuk penerimaan terhadap konsep lakilaki yang tidak ajeg. Begitupun dalam konsep tubuh, transman memaknai tubuhnya sebagai seorang laki-laki seutuhnya meskipun mereka terlahir sebagai perempuan. Tubuh yang ditampilkan oleh tokoh transman dalam film 3 Generations merupakan sebuah usaha yang dilakukan untuk menunjukkan identitas diri sebagai laki-laki dan penerimaan orang-orang yang ada di sekitarnya terhadap tubuh maskulin yang bukan hanya domain laki-laki normatif. 


\section{Daftar Pustaka}

Beasley, Chris (2005) GenderESexuality: Critical Theories, Critical Thinkers. London. Sage Publications

Butler, J. (1999). Gender Trouble. New York: Routledge.

Ekins, Richard \& King, Dave. (2006). "The Transgender Phenomenon". SAGE Publication. London.

Gardiner, Judith Kegan. (2012). Female Masculinity and Phallic Women. Dalam Feminist Studies, Vol. 38, No. 3. Feminist Studies, Inc. pp. 597-627.

Halberstam, Judith, (2002), "An Introduction to Female Masculinity" in Adams, Rachel \& Savran, David. The Masculinity Studies Reader. Blackwell Publisher: 355-374

Halberstam, Judith. (2005). "Drag Kings Masculinity and Performance" dalam Raiford Guins \& Omayra Z. Cruz (Eds) Popular Culture: A Reader. London. Thousand Oaks New Delhi: SAGE Publication, pp. 429-440.

Halberstam, Judith. (1998). "Transgender Butch: Butch/FTM Border Wars and the Masculinity Continuum. Durham. Duke University Press, pp. 287-301.

Hall, S. (1997). The work of representation. Representation: Cultural Representations and Signifying practices, 13-74.

Hines, Sally. (2007). "TransForming Gender; Transgender practice of identity, intimacy and care". The Policy Press. Bristol UK.

Noble, Jean Bobby. (2006). Sons of the Movement: FtMs Risking Incoherence on a PostQueer Landscape. Women's Press, an imprint of Canadian Scholars Press Inc. Toronto.

Rubin, Henry. (2003) Self made men : identity, embodiment, and recognition among transsexual men. Vanderbilt University Press. Nashville TN.

Suthrell, Charlotte. (2004). "clothing sex. Sexing Clothes: Transvestism. Material Culture and the Sex and Gender Debate" dalam Suthrell, Charlotte. Unzipping Gender: Sex, Crossdressing and Culture. BERG. Oxford. New York; 13-2

Aaron, Michelle (2001) The Boys Don't Cry debate: Pass/fail. Screen, Volume 42, Issue 1, Pages 97-102.

IMDb, (2016) 3 Generations. Artikel ulasan film, diakses di https://www.imdb.com/title/ tt4158624/pada tanggal 15 oktober 2018 